\title{
PENINGKATAN KEMAMPUAN BERCERITA MELALUI MEDIA BONEKA TANGAN PADA ANAK KELOMPOK B DI RAUDLATUL ATHFAL
}

\author{
Nur Hamidah ${ }^{1}$, Mursalim ${ }^{2}$ \\ ${ }^{1}$ Prodi PIAUD IAIN Jember \\ nurhamidah0686@gmail.com \\ ${ }^{2}$ IAIN Jember \\ salimabuya@gmail.com
}

\begin{abstract}
An ability to tell stories in early childhood needs to be supported by interesting media. One of the effective media for children is hand puppet media. Hand puppet media can develop communication, and activate children's cognitive and five senses. The purpose of this study was to analyze and describe the improvement of storytelling skills through hand puppet media. This study uses a qualitative approach, the data collection techniques are observation, interviews, and documentation. The validity of the data by source triangulation and technical triangulation. The results of this study found that improving the ability to tell stories through hand puppet media in group B children taught by educators RA Darus Salam Sumberbaru based on the advice of the principal. And the use of hand puppet media was carried out for five to eight meetings.
\end{abstract}

Keywords: storytelling ability, hand puppet media

\begin{abstract}
ABSTRAK
Suatu kemampuan bercerita pada anak usia dini perlu ditunjang dengan media yang menarik. Salah satu media yang efekif bagi anak yaitu media boneka tangan. Media boneka tangan dapat mengembangkan komunikasi, dan mengaktifkan kognitif serta panca indera anak. Tujuan penelitian ini untuk menganalisis dan mendiskripsikan peningkatan kemampuan bercerita melalui media boneka tangan. Penelitian ini menggunakan pendekatan kualitatif, teknik pengumpulan datanya dengan observasi, wawancara, dan dokumentasi. Keabsahan data dengan triangulasi sumber dan triangulasi teknik. Hasil penelitian ini menemukan bahwa peningkatan kemampuan bercerita melalui media boneka tangan pada anak kelompok B yang diajarkan oleh pendidik RA Darus Salam Sumberbaru berdasarkan dari himbauan kepala sekolah. Serta penggunaan media boneka tangan dilaksanakan sebanyak lima sampai delapan kali pertemuan.
\end{abstract}

Kata Kunci: kemampuan bercerita, media boneka tangan

\section{PENDAHULUAN}

Pendidikan nasional memiliki fungsi untuk mengembangkan suatu kemampuan dan membentuk watak serta peradaban bangsa yang bermartabat dalam mencerdaskan kehidupan 
bangsa, yang bertujuan untuk mengembangkan potensi peserta didik agar menjadi manusia beriman dan bertaqwa kepada Tuhan Yang Maha Esa, berakhlak mulia, sehat, berilmu, cakap, kreatif, mandiri, dan menjadi warga negara yang demokratis serta bertanggung jawab (Sekretariat Negara RI, 2003:7).

Undang-undang No. 20 Tahun 2003 tentang Sisdiknas bahwa jalur pendidikan adalah wahana yang dilalui peserta didik untuk mengembangkan potensi diri dalam suatu proses pendidikan yang sesuai dengan tujuan pendidikan (Sekretariat Negara RI, 2011:4).

Pendidikan anak usia dini merupakan salah satu bentuk penyelenggaraan pendidikan yang lebih menitikberatkan pada koordinasi motorik halus dan kasar, kecerdasan (daya pikir, daya cipta, emosi, dan spiritual), sosial emosional (sikap dan perilaku beragama), serta bahasa dan komunikasi, yang disesuaikan dengan keunikan dan berbagai tahapan perkembangan yang dilalui oleh anak (Suyadi \& Dahlia, 2017:28).

Pada dasarnya pendidikan anak usia dini merupakan suatu kegiatan bermain sambil belajar, karena pada masa ini anak sangat membutuhkan adanya unsur keleluasaan untuk bermain dan mengembangkan fungsi psikologis dalam dirinya yang berkaitan dengan permainannya. Bermain merupakan peluang bagi anak dalam melibatkan dirinya diberbagai kegiatan bermain yang dinikmatinya sebagai suatu suasana yang menyenangkan sehingga seluruh potensi anak dapat berkembang dengan baik. Kegiatan bermain tentu dilakukan dilingkungan sekitar anak, dengan menggunakan sarana, alat permainan edukatif, dan memanfaatkan sumber belajar yang ada disekitar. Kegiatan bermain juga harus menyenangkan, sehingga akan mendapatkan pengalaman yang kaya, baik pengalaman anak dengan dunianya sendiri, orang lain, maupun lingkungan sekitar. Oleh karena itu, pendidikan anak usia dini, perlu menyediakan beragam kegiatan dalam mengembangkan berbagai aspek perkembangan yang meliputi aspek moral dan nilai agama, seni, kognitif, bahasa, sosial emosional, kemandirian, dan fisik motorik.

Salah satu dari aspek perkembangan anak yang akan dibahas yakni aspek bahasa, yang didalamnya juga memuat salah satu kemapuan bercerita. Bahasa bagi anak usia dini berfungsi sebagai alat untuk berkomunikasi dengan lingkungan sekitarnya, mengembangkan kemampuan intelektual, mengembangkan ekspresi anak dan menyatakan perasaan serta sebuah pikirannya kepada orang lain. Bahasa juga bisa menjadi suatu sistem simbol untuk berkomunikasi dengan orang lain, yang meliputi daya cipta dan berbagai sistem aturan (Dhieni, dkk., 2018: 3).

Keterampilan berbicara pada anak juga dapat dikembangkan melalui percakapan sederhana yang dapat menarik dan mengalihkan perhatian orang lain. Mereka dapat menggunakan bahasa dengan berbagai cara seperti bertanya, berdialog dan bernyanyi (Isjoni, 2013:235).

Menurut Arsjad (2018:108) ia menyatakan bahwa kemapuan dalam berbicara juga dapat dilaksanakan melalui suatu diskusi, bercakap-cakap atau berdialog, wawancara, pidato, bercerita, sandiwara, pemberitaan, telepon-menelepon, rapat, ceramah, seminar, dan sebagainya. 
Kemampuan berbicara pada anak usia dini juga memerlukan metode yang menarik dan menyenangkan serta sesuai dengan tahapan perkembangan anak. Metode yang sesuai dan tepat digunakan untuk meningkatkan kemampuan berbicara pada anak adalah metode storytelling. Storytelling merupakan sebuah kegiatan untuk menyampaikan suatu cerita baik itu dalam bentuk kata-kata, gambar, suara kepada orang lain. Dan biasanya memang digunakan dalam proses pembelajaran yang objeknya ialah anak-anak.

Menurut Moeslichatoen (2004:157) cerita adalah serangkaian peristiwa yang saling terkait dalam suatu periode waktu, yang di dalamnya pembaca atau pendengar melihat tokoh-tokoh yang berperan, merasakan apa yang dirasakan oleh tokoh-tokoh itu, mengalami ketegangan karena perasaan yang muncul dan kelegaan ketika persoalan itu dapat diselesaikan. Anak usia dini senang sekali mendengarkan cerita, sehingga metode bercerita bisa dijadikan metode penunjang yang menarik bagi anak usia dini.

Kemampuan dalam bercerita perlu ditunjang dengan media yang menarik, karena dengan media pembelajaran yang menarik merupakan salah satu cara yang efektif dalam menanggulangi kelemahan persoalan pembelajaran yang masih bersifat konvensional. Dengan menggunakan media pembelajaran diharapkan dapat mempermudah dan mengefektifkan proses pembelajaran. Salah satu media yang efekif untuk anak yaitu media boneka tangan dengan adanya panggung yang tersedia. Media boneka tangan dapat menjadi salah satu alternatif dalam mengembangkan komunikasi beberapa arah, sehingga dapat mengaktifkan kognitif dan panca indera. Permainan boneka tangan dapat menarik perhatian anak dalam belajar sehingga anak merasa senang dalam melakukan proses pembelajaran (Madyawati, 2016:178).

Berdasarkan permasalahan yang ditemui dari hasil obervasi di RA Darus Salam Sumberbaru, bahwa masih terdapat anak dengan rentan usia 4-6 tahun yang berhadapan dengan sejumlah masalah pada aspek bahasa, seperti anak kurang mampu untuk mengungkapkan pesan yang disampaikan guru dikarenakan metode dan media pembelajaran yang kurang menarik, ada juga sejumlah kesulitan yang dihadapi anak-anak seperti merasa malu untuk berkomunikasi, belum berani menyimpulkan ide atau gagasan secara spontan. Kemudian melihat hal tersebut terdapat langkah yang diambil oeh lembaga yaitu menggunakan media boneka tangan dalam proses pelaksanaan belajar mengajar.

Terdapat penelitian yang relevan dengan penelitian ini, yakni hasil penelitian dari Evanofiana, Mahyuddin, \& Izzati (2019) bahwa terjadi adanya suatu peningkatan kemampuan bercerita yang dilakukan melalui permainan boneka jari di Taman kanak-kanak. Kemudian penelitian relevan yang selanjutnya dari Istirokah (2017) bahwa terdapat adanya suatu peningkatan kemampuan bercerita yang dilakukan melalui media rotasia pada anak didik kelompok A1 Tk Pamekar Budi Desa Candisari Kecamatan Mranggen Kabupaten Demak Semester 1 Tahun Pelajaran 2016/2017. 
Terdapat penelitian yang relevan juga dengan penelitian ini, yaitu penelitian Nugraha (2017) bahwa pelaksanaan proses pembelajaran dengan menggunakan media alat peraga pada mahasiswa di Laboratorium Program Studi Pendidikan Bahasa Dan Sastra Indonesia Tahun Pelajaran 2016/2017 dapat meningkatkan kemampuan bercerita.

Penelitian ini juga memiliki tujuan untuk menganalisis dan mendeskripsikan peningkatan kemampuan bercerita melalui media boneka tangan pada anak kelompok B di RA Darus Salam Sumberbaru. Kemudian manfaat secara teoritis diharapkan dapat digunakan untuk memberikan sumbangsih pemikiran untuk mendukung hasil penelitian orang lain tentang objek dan kondisi yang berbeda.

\section{METODE}

Pendekatan dalam penelitian ini menggunakan pendekatan kualitatif dan jenis penelitian deskriptif kualitatif. Subjek dalam penelitian ini adalah Kepala RA Darus Salam Sumberbaru, pendidik kelompok B RA Darus Salam Sumberbaru, siswa-siswi kelompok B RA Darus Salam Sumberbaru, serta wali murid RA Darus Salam Sumberbaru. Teknik pengumpulan data menggunakan observasi, wawancara, dan dokumentasi. Teknik analisis data yang digunakan adalah analisis data deskriptisf reflektif yang terdiri dari beberapa komponen yaitu: reduksi data, penyajian data, dan penarikan kesimpulan. Sedangkan Keabsahan data menggunakan triangulasi sumber dan triangulasi teknik.

\section{HASIL DAN PEMBAHASAN}

\section{Peningkatan Kemampuan Bercerita Melalui Media Boneka Tangan}

Terdapat berbagai manfaat yang dapat diperoleh dengan menerapkan media boneka tangan, seperti dapat membantu anak dalam mengemukakan pendapat, lebih meminimalisir waktu karena peralatan yang digunakan tidak terlalu banyak, dapat mendorong anak untuk mengembangkan daya imajinasinya, dapat membuat anak merasa senang saat melakukan proses pembelajaran.

Para pendidik RA Darus Salam Sumberbaru dalam rangka meningkatkan kualitas belajar mengajar lebih banyak menggunakan media boneka tangan. Berdasarkan hasil penelitian yang dilakukan oleh peneliti, pendidik memberikan suatu cerita pada anak-anak agar mereka senang dan tentu cerita yang digunakan mengandung unsur edukatif, yang bertujuan agar anak-anak tidak merasa jenuh dengan pembelajaran yang diberikan. Dalam pelaksanaan pembelajaran tersebut, para pendidik RA Darus Salam Sumberbaru tidak hanya sekedar menggunakan media boneka tangan dalam pembelajaran, akan tetapi berdasarkan arahan serta himbauan dari kepala sekolah, para pendidik juga mengikuti berbagai macam pelatihan yang nantinya akan menjadi tambahan ilmu serta pengalaman dalam mengajar. Serta para pendidik juga saling bertukar pikiran antar sesama guru yang nantinya diharapkan dapat menghasilkan kontribusi bagi pihak sekolah. 
Hasil temuan tentang peningkatan kemampuan guru dalam bercerita melalui media boneka tangan di RA Darus Salam Sumberbaru sesuai dengan penelitian terdahulu yang dilakukan oleh Evanofiana, Mahyuddin, \& Izzati (2019) bahwa terjadi adanya suatu peningkatan kemampuan bercerita yang dilakukan melalui permainan boneka jari di Taman kanak-kanak. Dan penelitian relevan yang selanjutnya dari Istirokah (2017) bahwa terdapat adanya suatu peningkatan kemampuan bercerita yang dilakukan melalui media rotasia pada anak didik kelompok A1 Tk Pamekar Budi Desa Candisari Kecamatan Mranggen Kabupaten Demak Semester 1 Tahun Pelajaran 2016/2017.

Temuan hasil penelitian ini sesuai dengan manfaat boneka tangan yaitu menurut Musfiroh (2008: 115), menyatakan bahwa boneka tangan adalah boneka yang terbuat dari kain yang dibentuk menyerupai wajah dan bentuk tubuh dari berbagai bentuk dengan berbagai macam jenis sifat yang dimainkan dengan menggunakan tangan dan digerakkan menggunakan jari-jari tangan. Boneka tangan juga merupakan media yang dapat membuat anak berimajinasi. Hal tersebut juga senada seperti yang disampaikan oleh Madyawati (2016: 186) bahwa boneka tangan dapat digunakan sebagai media pembelajaran yang menarik bagi anak, karena sangat efektif untuk membantu anak belajar berbahasa.

Dengan adanya rasa senang pada diri anak merupakan kemampuan dalam penguasaan kelas, merupakan simbol bahwa pengajaran tersebut dikatakan berhasil. Dengan segala upaya yang dilaksanakan oleh para guru diantaranya dengan menggunakan media, salah satunya adalah media boneka tangan. Dengan menggunakan media boneka tangan guru lebih mudah menerangkan dan memaparkan keterangan kepada anak didiknya dengan fasih dan lancar, karena dengan adanya media boneka tangan ini pula guru mendapat inovasi dalam menyampaikan suatu cerita kepada anak.

\section{Penggunaan Media Boneka Tangan dalam Peningkatan Kemampuan Bercerita pada Anak}

\section{Kelompok B di RA Darus Salam Sumberbaru}

Di RA Darus Salam Sumberbaru program bercerita melalui media boneka tangan itu sudah ada sejak dulu sebelum sekolah ini didirikan, karena banyak sekali manfaat dari media tersebut maka sekolah memilih program ini agar dapat diterapkan pada semua anak, dan lebih menarik dalam pembelajaran. Pada saat ini dengan kurikulum yang terbaru, bercerita melalui media boneka tangan wajib dilaksanakan. Karena dengan media tersebut anak akan mencapai tingkat tuntas yang sudah ditetapkan. Oleh karena itu guru yang juga mengikuti program ini yang nantinya juga bisa untuk melanjutkan aplikasinya pada pembelejaran. Hal itu disebabkan karena daya serap yang dimiliki oleh anak didik berbeda-beda (perbedaan individual), sehingga dalam penguasaan konsep bagi anak didik juga berbeda-beda. 
Pelaksanaan pengajaran bercerita melalui media boneka tangan di RA Darus Salam Sumberbaru dimana dalam observasi tersebut, peneliti melihat anak kelompok B yang sedang mengikuti pelajaran dengan menggunakan metode bercerita melalui media boneka tangan. Dan peneliti juga melihat mereka dengan seksama saat menyimak pelajaran yang disampaikan melalui bercerita dengan media boneka tangan. Setelah selesai dilaksanakan dan guru memeriksa hasil pelajaran, guru dapat tersenyum puas karena pembelajaran secara klasikal sudah dianggap memahami materinya.

Berdasarkan hasil observasi, guru RA Darus Salam Sumberbaru menggunakan metode pembelajaran yang bervariasi untuk memberikan pengetahuan pada setiap anak. Beberapa metode yang digunakan antara lain metode ceramah yang divariasikan dengan cerita karena biasanya anak usia dini suka bercerita. Penguasaan guru terhadap cerita dalam pemanfaatan metode bercerita melalui boneka tangan tersebut cukup baik. Hal ini ditunjukkan dari keaktifan anak di kelas, dan guru mampu mengelola kelas dengan baik selama kegiatan pembelajaran berlangsung. Selain memberikan pengetahuan kepada anak, sebagai guru yang profesional seorang guru juga harus mampu menjadikan dirinya sebagai pengganti orang tua anak dan sahabat baik bagi anak didiknya. Pelaksanaan bercerita melalui boneka tangan dalam setiap satu semester diadakan maksimal adalah lima sampai delapan kali. Setiap satu kompetensi dasar selesai diajarkan, lalu diadakan bercerita melalui boneka tangan, tetapi bisa juga dilaksanakan dua atau tiga kompetensi.

Guru sangat berperan dalam pengembangan berbagai potensi pada anak, salah satunya dalam aspek bahasa. Karena dalam hal ini anak sebelum memasuki sekolah telah membawa berbagai permasalahan contoh kecilnya seperti cara berbicara anak yang masih belum lancar dalam berbicara, dalam hal ini permasalahan tersebut harus bisa dirubah menjadi hal yang positif oleh guru. Melihat pendidikan yang diajarkan di RA Darus Salam Sumberbaru melalui metode bercerita dengan media boneka tangan telah bisa berjalan secara kondusif. Penggunaan media boneka tangan di RA Darus Salam Sumberbaru dapat meningkatkan kemampuan dalam bercerita bagi guru. Karena guru bukan hanya sebagai pendidik dan pengajar tetapi juga sebagai pengganti kedua orang tua anak saat ada di sekolah.

Hasil temuan tentang penggunaan media boneka tangan dalam meningkatkan kemampuan bercerita sesuai dengan penelitian yang terdahulu yang dilakukan oleh Istirokah (2017) dengan judul penelitian Peningkatan Kemampuan Bercerita Melalui Media Rotasia Pada Anak Didik Kelompok A1 TK Pamekar Budi Desa Candisari Kecamatan Mranggen Kabupaten Demak Semester 1 Tahun Pelajaran 2016/2017. Dan dalam penggunaan media boneka tangan dapat dilaksanakan dua kali dalam satu minggu.

Hasil temuan diatas juga sesuai dengan penelitian Madyawati (2016) yang menyatakan bahwa boneka tangan dapat digunakan sebagai media pembelajaran yang menarik bagi anak, karena sangat efektif untuk membantu anak belajar berbahasa. Dengan menggunakan media boneka 
tangan ini, memudahkan dalam menerangkan tentang cerita yang disampaikan mulai dari awal hingga berakhirnya cerita tersebut. Dengan menggunakan media boneka tangan, anak dapat menerangkan cerita dengan lebih lancar tanpa harus berteriak karena sudah adanya peraga. Melalui keterampilan bercerita anak-anak menjadi senang dan betah berasa di kelas sambil menyimak materi yang disampaikan.

Hal senada juga disampaikan oleh Musfiroh (2005:50) bahwa pemilihan bercerita dengan menggunakan boneka tangan akan tergantung pada usia dan pengalaman anak. Boneka tangan secara spontan dapat langsung digunakan anak tanpa ada skenario khusus dari guru. Guru hanya mengenalkan benda. Kemudian cara menggunakan boneka dan menyiapkan alat peraga pendukungnya seperti jarum suntik, jika temanya tentang main dokter-dokteran, kemudian anak dibiarkan secara mandiri untuk memainkan boneka. Guru hanya memotivasi saja atau hanya ikut bermain agar suasana bermain boneka tangan dapat lebih menarik.

Hal diatas juga sesuai dengan pendapat Suliyanto (2014:116) bahwa boneka tangan mendorong anak untuk menggunakan bahasa. Anak-anak menggunakan boneka tangan untuk mengungkapkan apa yang ada dipikiran mereka yang sesuai dengan imajinasinya.

Dari data diatas maka dapat dijelaskan bahwa penggunaan media boneka tangan dapat meningkatkan kemampuan bercerita mengenai materi yang disampaikan karena dengan bercerita anak dapat memahami tentang pelajaran yang ada di RA Darus Salam Sumberbaru. Dari data-data diatas dapat digambarkan penggunaan media boneka tangan memiliki peranan yang sangat besar dalam meningkatkan kemampuan bercerita anak usia dini.

\section{KESIMPULAN DAN SARAN}

Pertama, upaya untuk meningkatkan kemampuan guru dalam bercerita melalui media boneka tangan pada anak kelompok B telah dilaksanakan oleh guru RA Darus Salam Sumberbaru berdasarkan himbauan dari kepala sekolah, dengan mengikuti pelatihan-pelatihan, dan saling bertukar pikiran sesama guru.

Kedua, penggunaan media boneka tangan dalam meningkatkan kemampuan bercerita pada anak kelompok B di RA Darus Salam Sumberbaru dilaksanakan sebanyak lima sampai delapan kali pertemuan.

\section{DAFTAR PUSTAKA}

Arsjad, 2009. Model Model Pembelajaran Inovatif dan efektif. Jakarta: Puspa Swara.

Dhieni, Nurbiana., dkk. 2018. Metode Pengembangan Bahasa. Tangerang: Universitas Terbuka.

Evanofiana, Nina, Nenny Mahyuddin, \& Izzati. 2019. Peningkatan Kemampuan Bercerita Melalui Permainan Boneka Jari Di Taman Kanak-Kanak. JFACE Journal of Family, Adult, and Early Childhood Education, 1(2), 140-146. 
Huberman, Miles. 2002. Analisis Kualitatif. Jakarta: Rineka Cipta.

Isjoni. 2017. Model Pembelajaran Anak Usia Dini. Bandung: Alfabeta.

Istirokah. Peningkatan Kemampuan Bercerita Melalui Media Rotasia Pada Anak Didik Kelompok A1 TK Pamekar Budi Desa Candisari Kecamatan Mranggen Kabupaten Demak Semester 1 Tahun Pelajaran 2016/2017. JP3 (Jurnal Pendidikan dan Profesi Pendidik). ISSN 24773387(Print) | ISSN 2597-6516 (Online).

Madyawati, Lilis. 2016. Strategi Pengembangan Bahasa Pada Anak. Jakarta: Kencana.

Musfiroh, Tadkiroatun. 2008. Bercerita Untuk Anak Usia Dini. Yogyakarta: Tiara Wacana.

Moeslichatoen. 2004. Metode Pengajaran di Taman Kanak-kanak. Jakarta: Rineka Cipta.

Nugraha, Aries Setia. 2017. Peningkatan Kemampuan Bercerita Dengan Menggunakan Alat Peraga Pada Mahasiswa Yang Peraktik Di Laboratorium Program Studi Pendidikan Bahasa Dan Sastra Indonesia Tahun Pelajaran 2016/2017. LITERASI, Jurnal Ilmiah Pend. Bahasa, Sastra Indonesia dan Daerah, 7(2). e-ISSN 2549-2594.

Sekretariat Negara RI. 2003. Undang-undang Sistem Pendidikan Nasional. Jakarta: Sinar Grafika.

Sekretariat Negara RI. 2011. Undang-undang RI No. 20 Tahun 2003 Tentang Sisdiknas. Jakarta: Sinar Grafika.

Suyadi \& Dahlia. 2017. Implementasi dan Inovasi Kurikulum Paud 2013, Program pembelajaran Berbasis Multiple Intelligences. Bandung: Remaja Rosdakarya. 